Article

\title{
Geographic Disparity in Machine Intelligence Approaches for Archaeological Remote Sensing Research
}

\author{
Dylan S. Davis (i) \\ Department of Anthropology, The Pennsylvania State University, University Park, PA 16802, USA; \\ dsd40@psu.edu
}

Received: 7 February 2020; Accepted: 12 March 2020; Published: 12 March 2020

\begin{abstract}
A vast majority of the archaeological record, globally, is understudied and increasingly threatened by climate change, economic and political instability, and violent conflict. Archaeological data are crucial for understanding the past, and as such, documentation of this information is imperative. The development of machine intelligence approaches (including machine learning, artificial intelligence, and other automated processes) has resulted in massive gains in archaeological knowledge, as such computational methods have expedited the rate of archaeological survey and discovery via remote sensing instruments. Nevertheless, the progression of automated computational approaches is limited by distinct geographic imbalances in where these techniques are developed and applied. Here, I investigate the degree of this disparity and some potential reasons for this imbalance. Analyses from Web of Science and Microsoft Academic searches reveal that there is a substantial difference between the Global North and South in the output of machine intelligence remote sensing archaeology literature. There are also regional imbalances. I argue that one solution is to increase collaborations between research institutions in addition to data sharing efforts.
\end{abstract}

Keywords: machine intelligence; remote sensing; archaeology; ethics; data sharing; automated analysis

\section{Introduction}

The archaeological record holds important information about the past, but our understanding of human history is often patchy, incomplete, and disjointed, as datasets are unavailable or incompatible across research projects [1,2]. This is compounded by the fact that scientific observations are subjective, leading to biases in different analysis procedures [3]. Machine intelligence (MI) research (AI, machine learning, deep learning, etc.) provides powerful mechanisms for collecting more complete and systematic information from remote sensing instruments to inform researchers about the archaeological record. MI, in turn, can permit for more comprehensive-and reproducible-research into important anthropological questions [4-8].

The age of "big data" has resulted in the availability of extraordinarily large collections of information on global scales [1,9]. One example of "big data" are worldwide remote sensing datasets. With so much information at our disposal, the challenge lies in efficient and reproducible analysis [10-13]. It is within this set of challenges where MI research has made great strides, especially within remote sensing applications of cultural heritage and archaeological research [5,6,12,14-24]. MI encompasses statistical classifiers, semi-automated analysis, deep learning, machine learning, and other methods of systematically parsing through image data to extract information $[14,16,25]$. While a majority of this work has focused on the development of algorithms for detecting archaeological deposits from landscape-scale satellite and aerial imagery, and airborne laser scanning (ALS) $[6,12,26]$, research has 
also focused on analyzing individual materials and smaller-scale phenomena [4,20,22,23,27-29]. In the past several years, alone, there has been an explosion of machine learning research with archaeological remote sensing foci around the world (Figure 1).

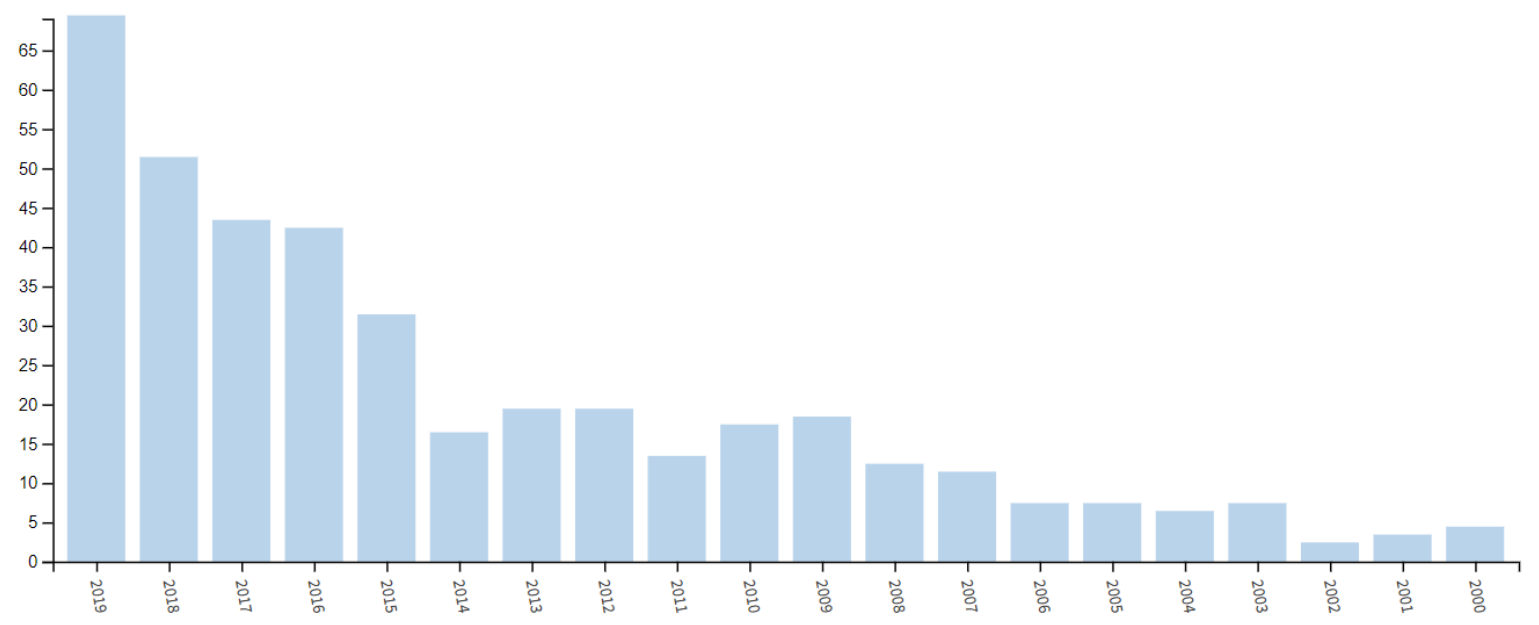

Figure 1. The number of publications $(n=408)$ on archaeological machine intelligence $(\mathrm{MI})$ since 2000 (source, Web of Science).

At the largest scale, MI can be used in conjunction with remote sensing datasets to help researchers document human system dynamics in a relatively complete manner, allowing for comprehensive studies of settlement and mobility patterns, effects of environmental change on human societies, ecological effects of anthropogenic land use, and other significant archaeological topics [10,14,30-34]. Without the aid of computer learning techniques, our knowledgebase often remains highly biased, with vast components of the archaeological record remaining hidden [35-37]. As demonstrated recently by ref [38], large portions of the world's archaeological knowledge are extremely limited, and data quality for these understudied regions are, likewise, poor. This geographic data-gap limits our ability to learn about the past. Cultural heritage protection is of great interest to many nations around the world (e.g., U.N. Resolution 2347 [39] declaring the destruction of cultural heritage a war crime), and computer algorithms can help to improve conservation and protection efforts [6,18,25,40-42].

Despite these abilities, there are imbalances in the use and development of MI methods for archaeological remote sensing throughout the world. Specifically, these methods are highly utilized by researchers in the Global North (e.g., United States and parts of Western Europe), but other regions produce very few studies, in comparison, dealing with archaeological MI applications for remote sensing (Figure 2). Elsewhere, my colleagues and I have discussed this issue, illustrating that important developments in automated archaeological procedures have been underrepresented in archaeological literature from developing countries, particularly those in the Southern hemisphere [6,43]. However, robust quantitative evaluation of the problem within archaeology has not yet been undertaken.

Here, I attempt to quantify the extent to which this disparity exists globally and explore the possible reasons for the geographic imbalance in the output of MI research. Then, I lay out some possible solutions to this growing problem. I argue that one solution is via a combined effort of active data sharing (including code and workflow procedures) and interdisciplinary and inter-institutional collaboration. These suggestions for future developments are not limited to studies of archaeology and cultural heritage, but rather warrant consideration by all disciplines involved in MI research. 


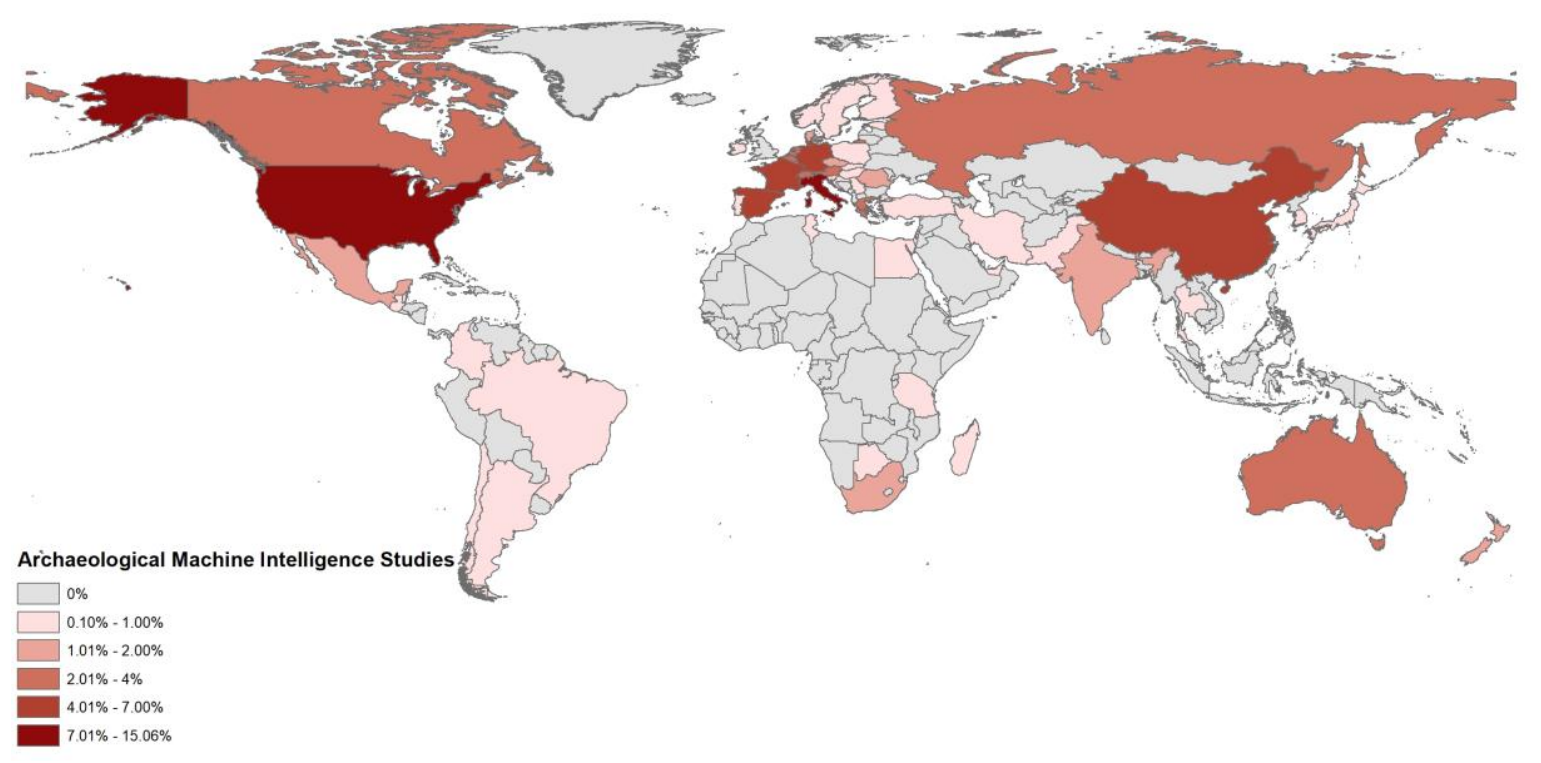

Figure 2. The percentage of papers $(n=148)$ published on machine intelligence for archaeological research (as of December 2019). This includes automated and semi-automated algorithms, AI, etc. developed for archaeology. Data collected from Web of Science.

\section{A Brief Overview of Machine Intelligence Research in Archaeological Remote Sensing}

The quantitative turn in archaeology began as early as the 1960s [44-48], as statistics and modeling became commonplace. Beginning in the 21st century, advancements in data quality, processing techniques, and availability of computing sources allowed for the many successes of landscape archaeology in prior decades (e.g., site and artifact detection, viewing landscapes as palimpsests, etc.) to be expanded upon. These expansions occurred both in terms of unprecedented speeds and levels of coverage $[17,25,49-51]$. The development of predictive models for archaeological site detection, which started in the 1980s with explosions in satellite and aerial image availability [52], were invaluable for expediting surveys and protecting these locations [53-57]. For example, in Spain and Portugal, the use of automated remote sensing analyses to record Iron Age settlement structures resulted in the detection and subsequent confirmation of over 300 new archaeological sites throughout the Iberian Peninsula over the past several years [7]. Additionally, recent work in Madagascar-which is critically understudied archaeologically-surveyed and identified over 70 new archaeological sites (and hundreds of potential sites) across an area of over $1000 \mathrm{~km}^{2}$ over the past year [55]. Prior to the use of semi-automated remote sensing methods, most of the coastline in this region was either unsurveyed or understudied.

Since the turn of the 21st century, a number of significant improvements in MI methods have significantly increased the accuracy and discovery of archaeological materials within remote sensing datasets [12,25]. Object-based image analysis (OBIA)—an MI method that uses morphometric and spectral parameters to identify features in image data [58-60]- has been successfully utilized by archaeologists since 2006 [6] and has resulted in extremely high accuracy for detecting archaeological sites around the world $[14,21,61,62]$. OBIA has also been successful in identifying artifact compositions (which yield insights to manufacturing processes and material origins) and even microscopic classification of mineral inclusions in cultural materials [24].

Advances in neural network analysis—a deep learning method of pattern recognition [63]—has recently provided additional improvements to archaeological remote sensing, improving site detection on landscape scales $[5,26,64]$. Such MI work has increased site discovery rates and are particularly important for areas with increased risk to cultural heritage preservation. While such developments in MI have been met with skepticism from researchers within archaeology [65-67], they have proven their 
abilities in maximizing archaeological knowledge with reduced time requirements and interobserver biases $[6,10,11,25,26]$.

Part of the need for such automated remote sensing analysis methods in archaeology is the increasing complexity of datasets (e.g., multispectral sensors, 3D datasets, time series, etc.) which make manual analysis challenging and time-consuming [11,49]. Landscape-scale data (e.g., satellites, ALS, and aerial imagery) contain vast geographic spaces, as well as multiple data levels, and provide important information about past settlement and human-environmental relationships, socio-political organization, and a myriad of other topics. Smaller-scale analyses of sites, individual features and artifacts, and even microanalysis of material composition also contain increasingly complicated data, and MI can assist in understanding architectural developments, living strategies, settlement histories, economic trade networks, and technological development [20,22-24,27-29,68,69].

Archaeological applications of MI are imperfect, of course, and issues with false positives and overall accuracy remain a concern $[6,70]$. Nonetheless, these issues have decreased substantially over the past decade, and advancements in MI are reducing these problems even further, often achieving accuracies of $>95 \%[5,21,26,64,71]$. For a detailed discussion of MI applications in archaeology, see refs $[6,11,12,24]$.

\section{Geographic Disparities within Archaeological Machine Intelligence}

While applications of MI work have made great strides in archaeology and cultural heritage applications, there are still substantial barriers to the propagation of this research. To quantify the geographic imbalance of MI analysis in remote sensing archaeology, I conducted a bibliographic analysis using the Web of Science search engine of publications from the late 20th century through 2019. Search terms were selected using the following algorithm:

TS $=\left(\left(\right.\right.$ automat $^{*}$ AND image analysis AND archaeol $\left.{ }^{*}\right)$ OR $\left(\right.$ semi-automat $^{*}$ detection AND archaeol $\left.^{*}\right)$ OR (machine learning AND archaeol*) OR (deep learning AND archaeol*) OR (artificial intelligence AND $\operatorname{archaeol}^{*}$ ) OR (supervised classification AND archaeol*) OR (unsupervised classification AND archaeol*) OR (object based image analysis AND archaeol $^{*}$ ) OR (neural network AND archaeol*))

These terms provide for any automated approaches to archaeology or archaeological image analysis, artificial intelligence or machine learning techniques, or statistical classification methods that provide for machine intelligence work. The results yielded a total of 148 references spanning multiple disciplines within archaeological research. Additional references collected by recent literature reviews $[6,11,25]$ were also consulted. Following this analysis, another algorithm containing the same search terms minus "archaeol*" was used to assess MI research across disciplines to compare to archaeological applications.

One limitation of the Web of Science search engine is that it excludes many journals with relevant literature. To correct for this limitation, I ran a second analysis with similar search terms using Microsoft Academic, another search engine for scholarly literature, to identify any potentially excluded publications (Table 1). In what follows, I report the findings of the Web of Science and Microsoft Academic analyses. 
Table 1. Search terms used in Microsoft Academic literature search. Microsoft Academic works using topics, rather than keywords like Web of Science. As such, search terms are not exactly the same as Web of Science (WoS) searches, but encompass the same overall concepts and methods. Results indicate a strong leaning towards North American and Western European institutions.

\begin{tabular}{ccc}
\hline Search Terms & Number of Results & Top Institutions Affiliated with Publications \\
\hline $\begin{array}{c}\text { Machine learning AND } \\
\text { archaeology }\end{array}$ & 102 & $\begin{array}{c}\text { Northwestern University (USA) } \\
\text { Harvard University (USA) } \\
\text { University of Washington (USA) }\end{array}$ \\
$\begin{array}{c}\text { Artificial intelligence AND } \\
\text { archaeology }\end{array}$ & 545 & $\begin{array}{c}\text { Vienna University of Technology (Austria) } \\
\text { Ghent University (Belgium) } \\
\text { University of Vienna (Austria) }\end{array}$ \\
$\begin{array}{c}\text { Archaeology AND automation } \\
\text { Deep-learning AND archaeology }\end{array}$ & 37 & $\begin{array}{c}\text { HafenCity University Hamburg (Germany) } \\
\text { Polytechnic University of Milan (Italy) } \\
\text { Vienna University of Technology (Austria) }\end{array}$ \\
\hline $\begin{array}{c}\text { Washington University (USA) } \\
\text { artificial neural network AND } \\
\text { archaeology }\end{array}$ & 7 & $\begin{array}{c}\text { University of Ontario (Canada) } \\
\text { Norweigen Computing Center (Norway) }\end{array}$ \\
\hline Centre National de la Recherche Scientifique \\
(France)
\end{tabular}

This review of automated and AI applications in archaeology reveals a disparity in where this work is being conducted and who develops these methods (Figures 1 and 2). According to Web of Science, most archaeological MI research originates from a handful of USA and Italian institutions, with other parts of the world largely absent. This is substantiated by Microsoft Academic results. There is a great disparity between the Global North and South (Australia is an exception), with very few developments coming from African or South American institutions. Additionally, there are divides within regions as well; one example is the divide between Eastern and Western Europe, with most publications originating from Western European institutions. This trend is statistically similar to MI research outside of archaeology $(t=-0.31165, \mathrm{df}=518.81$, $\mathrm{p}$-value $=0.7554)$ (Figure 3 ).

One potential reason for this imbalance stems from funding opportunities [43,72]. When analyzing published archaeological MI literature in Web of Science, most studies were conducted by affiliates of France's Centre National de la Recherche Scientifique (CNRS), Italy's Consiglio Nazionale delle Ricerche (CNR), the Chinese Academy of Sciences, and the University of California system in the United States (Figure 4). Similarly, most research has been funded by USA and European agencies, with China and Australia also making notable contributions (Figure 5), and this trend is followed by MI research, generally.

When assessing these trends outside of Web of Science, specifically, similar trends were observed, with the United States, Austrian, Italian, German, French, Canadian, and Norwegian institutions leading the field in nearly every category searched (see Table 1). Mongolia also emerged as a top country in the publication of neural network literature linked to archaeology. 

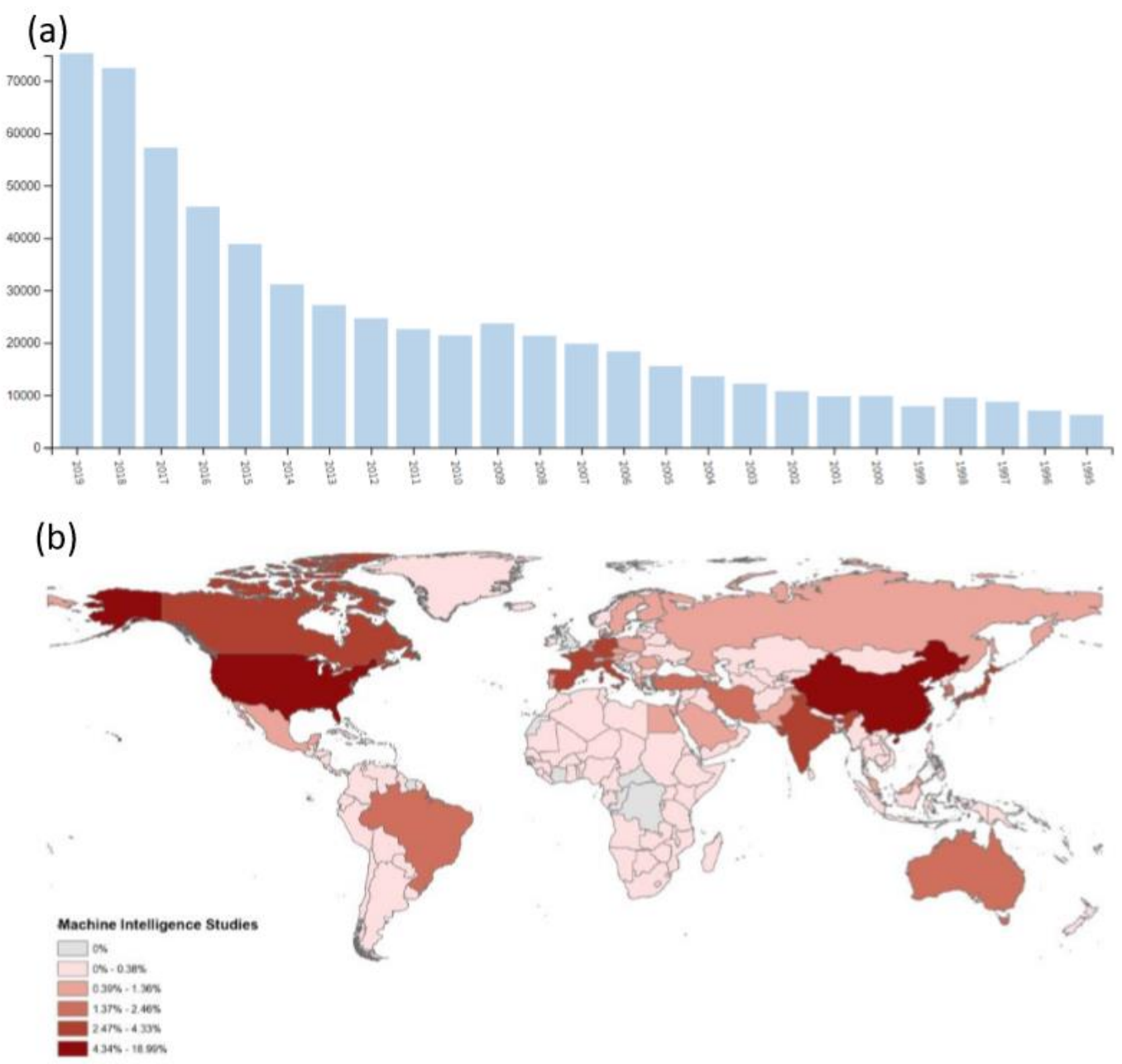

Figure 3. Quantity and geographic distribution of MI research $(n=621,630)$. (a) Graph of the total number of publications on MI work in all disciplines since the 1990s included in the Web of Science database. (b) Geographic distribution of MI studies in panel (a), indicating a concentration of development in North America, China, and parts of Europe (primarily in the West). South America and Africa contain the lowest percentage of MI research output. This result concurs with Microsoft Academic search queries.

Funding appears to be a major contributor to these imbalances, as most studies published originate from countries where funding sources are acquired. Likewise, most automated archaeological studies focus on regions within well-funded nations (e.g., Europe [6]). For example, researchers in Spain used data collected from MI procedures to conduct an analysis of settlement distribution within Spain and Portugal and its environmental context using an unprecedented sample size and geographic extent [7]. This provided new insight into the similarities of habitations in the Iberian Peninsula that were previously unknown. In the United States, freely available ALS data permitted for the development of an automated mound detection algorithm that identified hundreds of new potential archaeological deposits $[14,31]$. Likewise, in China, researchers developed an automated mound detection algorithm resulting in the identification of almost 150 new tomb sites [62]. These advancements are less often seen in the Global South (some exceptions include $[40,73,74]$ ) and when conducted are often led by scholars from institutions in the Global North (e.g., Europe or North America).

In the developing world, where funding is limited compared to places like Europe, foreign scholars with monetary support tend to be responsible for the development of MI methods (when they exist) [43]. A survey conducted by ref [72] found that most R\&D expenditures in Africa are covered by international grants outside of the African continent. This funding issue is compounded 
by comparatively limited training opportunities and necessary infrastructure for such techniques in institutions within developing countries [72,75].
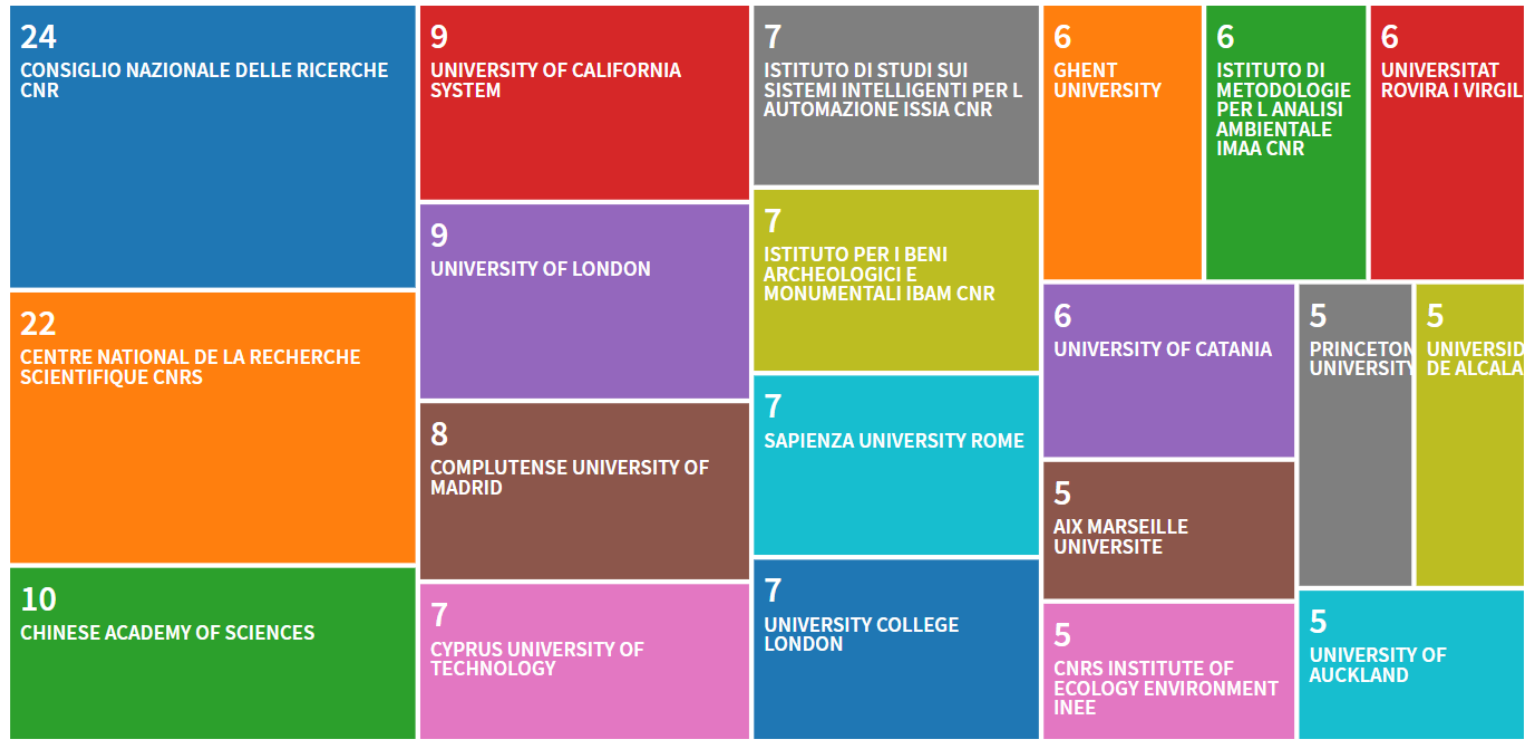

Figure 4. Top institutions producing archaeological MI research contained in Web of Science. These do not represent the total number of published studies, but illustrate disparities within certain journals (source, Web of Science). Results from Microsoft Academic indicate similar results.
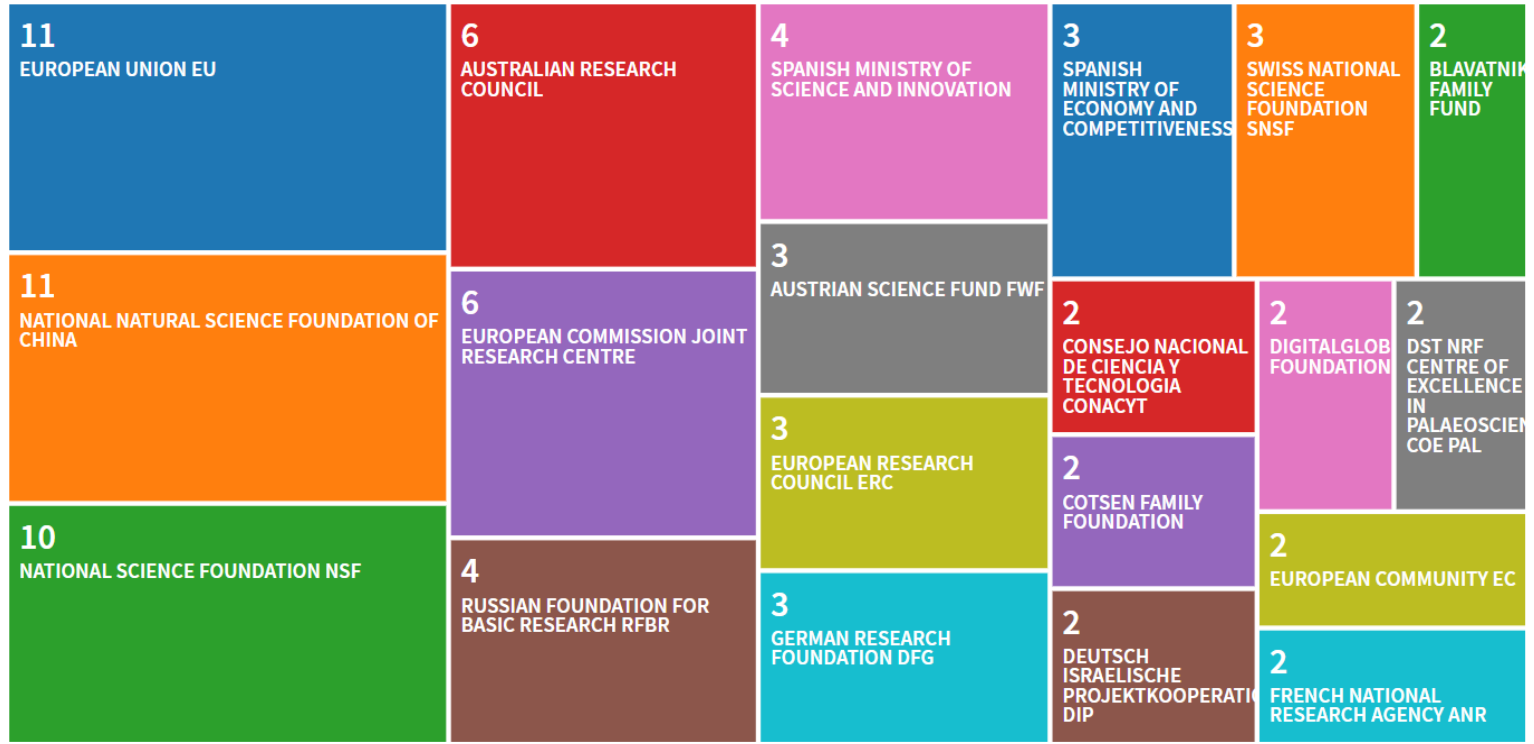

Figure 5. Top funding agencies for archaeological MI research published in Web of Science. These do not represent the total number of published studies, but illustrate disparities within certain journals (source, Web of Science). Results from Microsoft Academic indicate similar results.

\section{Potential Solutions to the Global Divide in Machine Intelligence Research}

There are solutions to this growing problem of inequality. First, we must prioritize data sharing and open-access repositories for datasets, code, protocols, and other workflows needed to develop and replicate computational algorithms [6,76-78]. While becoming more commonplace, many researchers still do not make their datasets or code/workflows available in publications or other publicized platforms for other researchers to use and build upon. Many journals now require data availability statements, but a lot of data are still under embargo by researchers and some funding agencies. 
For example, large datasets (e.g., LiDAR/ALS) collected by well-funded research consortia are often not released to researchers due to governmental or other restrictions, which limits the ability of researchers without such funding to develop new methods of assessing these datasets.

With the availability of numerous computer languages and software for machine learning and other automated analysis procedures (e.g., Google Earth Engine, R, Python, Keras and Tensorflow, etc.), the cost of developing new MI methods is not always a barrier to innovation; rather it is the acquisition of suitable datasets to analyze using MI. As such, the availability of costly and expansive datasets (which single research teams cannot adequately analyze alone) makes collaboration essential for good scientific practice and increased rates of discovery. For example, using manual analysis, researchers required two weeks to analyze a $10 \mathrm{~km}^{2}$ area for archaeological deposits [79]. In the same amount of time, automated methods were used to evaluate over $2000 \mathrm{~km}^{2}$ with similar levels of success [14]. Recent MI developments by archaeologists have released code and software to permit for replication and use by other researchers [4,80], and this must become standard practice.

Second, there is a need for inter-institutional and international collaborations of researchers across disciplines involving humanities and social science as well as computer science, geophysics, and other related computational fields. According to Web of Science, the top authors of archaeological machine intelligence research are primarily from European institutions (i.e., Italy, France, and Spain). Furthermore, researchers often collaborate with others from the same or nearby institutions. This results in the continued dominance of specific areas and institutions in producing MI research (Figures 2 and 3). By forming multidisciplinary collaborations between disciplines (e.g., social sciences, humanities, and computational mathematics and sciences) we can develop powerful analysis methods for addressing anthropological questions. Furthermore, and equally as important, by creating inter-institutional (and international) collaborations, the geographic disparity of machine intelligence research, in general, can be alleviated; in such circumstance's skillsets are shared between collaborators and novel methods are applied in new regions. While establishing and maintaining these collaborations is difficult, especially across large geographic distances [81], research has shown that international and inter-institutional collaborations are more impactful than non-collaborative efforts [82].

Furthermore, seeing as the majority of funding agencies are based in the Global North (e.g., Europe, USA, etc.), geographic disparities in where MI research is undertaken can be alleviated by an effort on the part of funding agencies to support work conducted in underrepresented areas. In Africa, for example, questions concerning the evolution of early humans and eventual expansion of Homo sapiens out of Africa can potentially be linked to remote sensing and machine learning methods. Additionally, recording of at-risk cultural heritage from significant periods of human development $[41,83]$ and cultural adaptations to climate change [84,85] can (and should) be viewed as a research priority within Africa, which automated remote sensing approaches are capable of investigating. Similarly, questions concerning settlement distribution of populations in high-altitude environments can be assessed utilizing automated remote sensing procedures in places like the Andes in South America. If researchers attempt to frame their machine learning studies within larger research programs, funding agencies may increase support for investigations in locations that have been largely understudied using MI methods.

Third, training in MI methods must be expanded to more institutions globally. Recent policy initiatives by countries like the United Arab Emirates, Qatar, South Africa, and Tunisia will hopefully see the rise in AI education and development in the Middle East and Africa [86]. Indeed, publications on automated archaeology in Africa and South America listed in the Web of Science databases all date to after the adoption of these initiatives (ca. 2018), and other publications from under-represented regions also follow these recent trends [6]. In MI research in general, publications have increased in these areas substantially since 2015. Nonetheless, the challenge to developing MI training opportunities lies in the lack of technological infrastructure needed to develop such computational programs [75].

As countries increase economic priorities on technological developments, disparities in computational research should begin to dissipate, but if (and when) this will happen is entirely 
uncertain. While we wait for governments to designate funding for such goals, the divide continues to grow, and it is an ethical concern that all researchers should be attuned too. Scholars fortunate enough to work in the developed world, where MI research is growing, should attempt to close this deepening global divide by engaging in ethical data sharing practices and collaborative efforts as detailed above. This is one way by which we, as researchers, can do our part in alleviating an increasing problem in the computational sciences.

Nevertheless, each of these suggestions, alone, is not enough to make a substantial difference in the widening geographic disparity within automated archaeological research. Rather, each step is a piece of a puzzle that together will assist in closing this divide (Figure 6). While advocations for data sharing have been a staple of archaeological literature for decades $[77,78,87,88]$, it is clear that more is needed. This is especially necessary with the advent of increasingly complicated methods like machine learning.

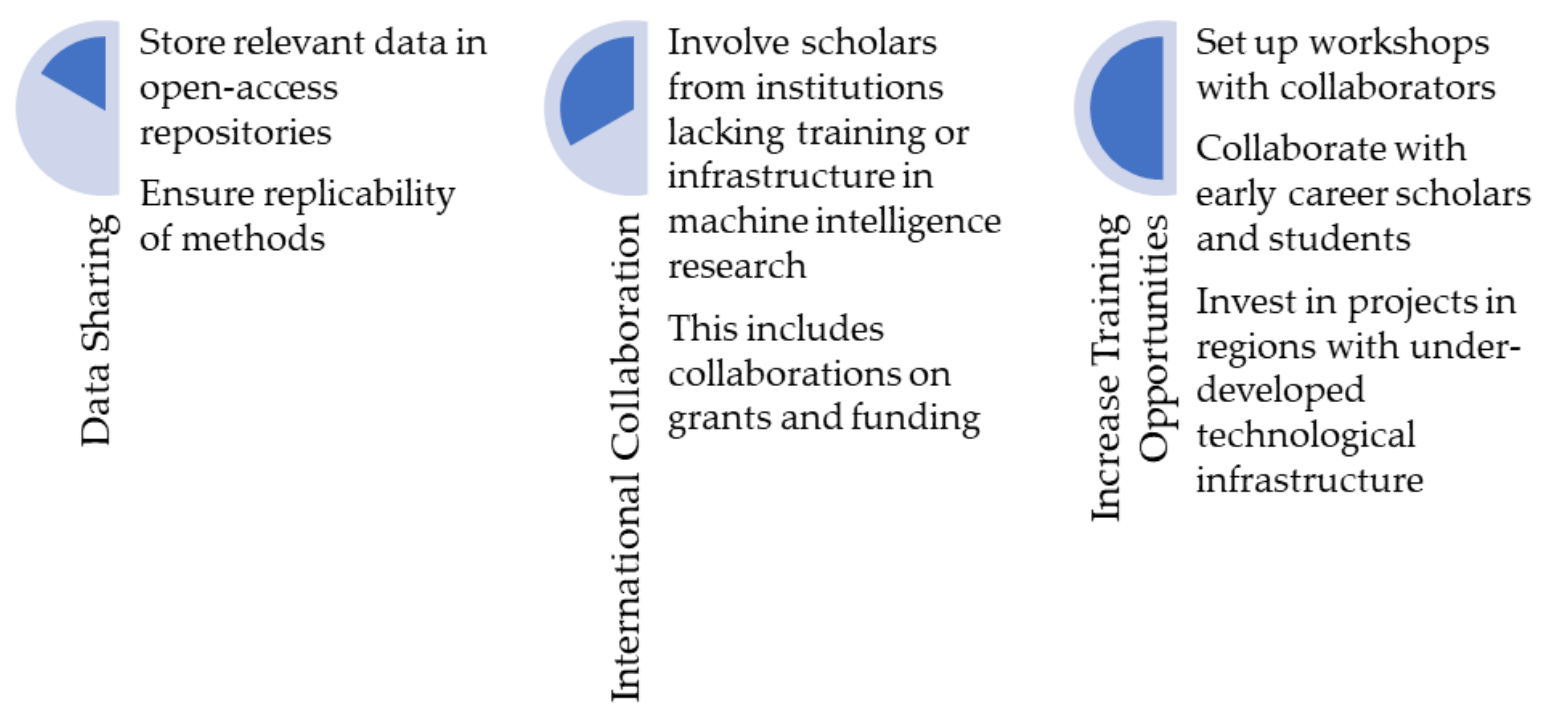

Figure 6. Graphical representation of the different steps necessary to address the geographic disparity in machine intelligence approaches within archaeology. Data sharing, while necessary, is not enough to decrease this widening gap in archaeological development.

To accelerate this effort, researchers should be made aware of economical, or entirely free ways of learning and utilizing MI approaches in their work. Table 2 provides a non-comprehensive list of some of the more popular open-source software and programming languages used for MI applications, as well as a link to a tutorial for each platform listed. There are dozens of additional resources, including plugins for GIS programs, cloud-based services, and packages for languages like R and Python, which perform general-to-specific computer automation tasks. As such, this table should serve as a starting point for researchers who are interested in learning and developing MI skills. 
Table 2. Some open-source resources for machine learning and computer-automated research.

\begin{tabular}{|c|c|c|}
\hline Platform Name & Tutorials and Resources & Platform Download URL \\
\hline Shogun & $\begin{array}{l}\text { https://www.shogun-toolbox.org/ } \\
\text { examples/latest/index.html }\end{array}$ & https://www.shogun-toolbox.org/ \\
\hline Tensorflow & https://www.tensorflow.org/tutorials & https://www.tensorflow.org/ \\
\hline Keras & $\begin{array}{c}\text { https://keras.io/\#getting-started-30-s- } \\
\text { to-keras }\end{array}$ & https://keras.io/ \\
\hline Google Earth Engine & $\begin{array}{l}\text { https://developers.google.com/earth- } \\
\text { engine/tutorials }\end{array}$ & https://earthengine.google.com/ \\
\hline Python & https://docs.python.org/3/tutorial/ & https://www.python.org/ \\
\hline $\mathrm{R}$ & $\begin{array}{l}\text { https://cran.r-project.org/doc/contrib/ } \\
\text { Paradis-rdebuts_en.pdf }\end{array}$ & https://www.r-project.org/ \\
\hline SAGA GIS & https://sagatutorials.wordpress.com/ & http://www.saga-gis.org/en/index.html \\
\hline ORFEO Toolbox & $\begin{array}{l}\text { https: } \\
\text { //www.orfeo-toolbox.org/CookBook/ }\end{array}$ & https://www.orfeo-toolbox.org/ \\
\hline GRASS GIS & https://grass.osgeo.org/support/ & https://grass.osgeo.org/ \\
\hline Whitebox GAT & $\begin{array}{l}\text { https://jblindsay.github.io/wbt_book/ } \\
\text { intro.html }\end{array}$ & $\begin{array}{c}\text { https: } \\
\text { //jblindsay.github.io/ghrg/Whitebox/ }\end{array}$ \\
\hline InterImage & $\begin{array}{c}\text { http://www.lvc.ele.puc-rio.br/ } \\
\text { projects/interimage/documentation/ }\end{array}$ & $\begin{array}{l}\text { http://www.lvc.ele.puc-rio.br/projects/ } \\
\text { interimage/ }\end{array}$ \\
\hline $\begin{array}{l}\text { ILWIS: Integrated Land } \\
\text { and Water Information } \\
\text { System }\end{array}$ & https://www.itc.nl/ilwis/users-guide/ & $\begin{array}{l}\text { https://gisgeography.com/ilwis- } \\
\text { integrated-land-and-water- } \\
\text { information-management/ }\end{array}$ \\
\hline
\end{tabular}

Example of Solutions in Action

While many of these suggestions are not novel, they have been effective when applied in different places around the world $[78,89,90]$. One recent example stems from my work in Madagascar. In collaboration with a large team of local archaeologists, the Morombe Archaeological Project (MAP) [90], we were able to formulate a research program focused around semi-automated remote sensing archaeology in Southwest Madagascar. Collaborators from MAP and the nearby University of Toliara assisted in planning the research, carrying out fieldwork operations, analyzing materials recovered, and publishing the results [55].

The data required to replicate the methods implemented in ref. [55] were subsequently stored on an open-access repository sponsored by Penn State (ScholarSphere), allowing for researchers around the world, including in Madagascar, to access the necessary datasets and replicate the study independently. Additionally, funding being sought for the continuation of this project includes local Malagasy collaborators on grant applications (either as project members or co-investigators). This helps to ensure that research conducted is as collaborative as possible at all stages of investigation [90].

Future plans incorporate the third suggested solution presented above, as we aim to set up a workshop in Madagascar focused on remote sensing and automated methods for archaeological prospection. The outcomes of these actions have already resulted in a substantial increase in systematic survey coverage of the study area in Southwest Madagascar, and illustrate the importance, and validity, of the aforementioned solutions to the growing issue of geographic disparity in MI remote sensing work.

\section{Conclusions}

Scientific observations are subjective [3] and as such require reproducible methods for deriving information. MI can provide a means of acquiring and deriving data from the archaeological record in systematic and reproducible ways, and by doing so can reveal substantial information that was previously overlooked. For example, the use of computer automation techniques to analyze 
remote sensing data has permitted researchers to map out cultural practices to their geographic extents [7,8], and fill important gaps in the archaeological record in other regions, thereby permitting for cross-regional comparisons and more robust analyses of past human activities $[7,21]$. These systematically acquired data provide key insights into sociopolitical organization, cultural boundaries, human-environmental relationships, and demographic changes.

Since the turn of the 21st century, machine intelligence approaches to archaeological remote sensing research have increased exponentially, and this trend is likely to continue well into the future. As I demonstrate here, this research has a strong geographic bias, which has continued to grow over the first two decades of the 21st century. To ensure that the current geographic disparities in the developments of these methods do not continue to grow, we must encourage complete data sharing (in the form of code, datasets, protocols, etc.) and collaborations between different researchers from different types of institutions.

The need for data availability and collaboration also constitute ethical issues within computer learning in general, for the lack of funding by many global institutions often prevents their researchers from contributing to this ever-growing field of study. Such developments are imperative, however, as cultural heritage continues to disappear around the world from violent conflict, development, and climate change. In order to learn about (and from) the past, we require complete datasets and the ability to replicate complex calculations, both of which are offered by machine intelligence applications.

Author Contributions: D.S.D. designed and implemented the experiments, analyzed the research results, and wrote the paper. All authors have read and agreed to the published version of the manuscript.

Funding: This paper was written with support from the National Aeronautics and Space Administration under Grant No. NNX15AK06H issued through the PA Space Grant Consortium. The Department of Anthropology at Penn State also contributed to publication costs.

Acknowledgments: I wish to thank the anonymous reviewers who provided invaluable feedback which substantially improved the text.

Conflicts of Interest: The author declares no conflict of interest. The funders had no role in the design of the study; in the collection, analyses, or interpretation of data; in the writing of the manuscript, or in the decision to publish the results.

\section{References}

1. Snow, D.R. Enhanced: Cybertools and archaeology. Science 2006, 311, 958-959. [CrossRef]

2. Data, Now Bigger and Better; Boellstorff, T.; Maurer, B. (Eds.) Prickly Paradigm Press: Chicago, IL, USA, 2015.

3. Proietti, M.; Pickston, A.; Graffitti, F.; Barrow, P.; Kundys, D.; Branciard, C.; Ringbauer, M.; Fedrizzi, A. Experimental test of local observer independence. Sci. Adv. 2019, 5, eaaw9832. [CrossRef]

4. Orengo, H.A.; Garcia-Molsosa, A. A brave new world for archaeological survey: Automated machine learning-based potsherd detection using high-resolution drone imagery. J. Archaeol. Sci. 2019, 112, 105013. [CrossRef]

5. Verschoof-van der Vaart, W.B.; Lambers, K. Learning to look at LiDAR: The use of R-CNN in the automated detection of archaeological objects in lidar data from the Netherlands. J. Comput. Appl. Archaeol. 2019, 2, 31-40. [CrossRef]

6. Davis, D.S. Object-based image analysis: A review of developments and future directions of automated feature detection in landscape archaeology. Archaeol. Prospect. 2019, 26, 155-163. [CrossRef]

7. Cerrillo-Cuenca, E.; Bueno-Ramírez, P. Counting with the invisible record? The role of LiDAR in the interpretation of megalithic landscapes in south-western Iberia (Extremadura, Alentejo and Beira Baixa). Archaeol. Prospect. 2019, 1-14. [CrossRef]

8. Freeland, T.; Heung, B.; Burley, D.V.; Clark, G.; Knudby, A. Automated feature extraction for prospection and analysis of monumental earthworks from aerial LiDAR in the Kingdom of Tonga. J. Archaeol. Sci. 2016, 69, 64-74. [CrossRef]

9. Cooper, A.; Green, C. Embracing the complexities of 'big data' in archaeology: The case of the english landscape and identities project. J. Archaeol. Method Theory 2016, 23, 271-304. [CrossRef] 
10. Bennett, R.; Cowley, D.; De Laet, V. The data explosion: Tackling the taboo of automatic feature recognition in airborne survey data. Antiquity 2014, 88, 896-905. [CrossRef]

11. Lambers, K. Airborne and spaceborne remote sensing and digital image analysis in archaeology. In Digital Geoarchaeology; Siart, C., Forbriger, M., Bubenzer, O., Eds.; Springer: Cham, Switzerland, 2018; pp. 109-122. ISBN 978-3-319-25314-5.

12. Traviglia, A.; Torsello, A. Landscape pattern detection in archaeological remote sensing. Geosciences 2017, 7, 128. [CrossRef]

13. Arvor, D.; Belgiu, M.; Falomir, Z.; Mougenot, I.; Durieux, L. Ontologies to interpret remote sensing images: Why do we need them? GISci. Remote Sens. 2019, 1-29. [CrossRef]

14. Davis, D.S.; Lipo, C.P.; Sanger, M.C. A comparison of automated object extraction methods for mound and shell-ring identification in coastal South Carolina. J. Archaeol. Sci. Rep. 2019, 23, 166-177. [CrossRef]

15. Cerrillo-Cuenca, E. An approach to the automatic surveying of prehistoric barrows through LiDAR. Quat. Int. 2017, 435, 135-145. [CrossRef]

16. Lambers, K.; Verschoof-van der Vaart, W.; Bourgeois, Q. Integrating remote sensing, machine learning, and citizen science in dutch archaeological prospection. Remote Sens. 2019, 11, 794. [CrossRef]

17. Lasaponara, R.; Masini, N. Image enhancement, feature extraction and geospatial analysis in an archaeological perspective. In Satellite Remote Sensing; Lasaponara, R., Masini, N., Eds.; Springer: Dordrecht, The Netherlands, 2012; Volume 16, pp. 17-63. ISBN 978-90-481-8800-0.

18. Lasaponara, R.; Leucci, G.; Masini, N.; Persico, R. Investigating archaeological looting using satellite images and GEORADAR: The experience in Lambayeque in North Peru. J. Archaeol. Sci. 2014, 42, 216-230. [CrossRef]

19. Trier, Ø.D.; Pilø, L.H. Automatic detection of pit structures in airborne laser scanning data: Automatic detection of pits in ALS data. Archaeol. Prospect. 2012, 19, 103-121. [CrossRef]

20. Sanger, M.C. Determining depositional events within shell deposits using computer vision and photogrammetry. J. Archaeol. Sci. 2015, 53, 482-491. [CrossRef]

21. Guyot, A.; Hubert-Moy, L.; Lorho, T. Detecting neolithic burial mounds from LiDAR-derived elevation data using a multi-scale approach and machine learning techniques. Remote Sens. 2018, 10, 225. [CrossRef]

22. Aprile, A.; Castellano, G.; Eramo, G. Combining image analysis and modular neural networks for classification of mineral inclusions and pores in archaeological potsherds. J. Archaeol. Sci. 2014, 50, 262-272. [CrossRef]

23. Hofmann, P.; Marschallinger, R.; Unterwurzacher, M.; Zobl, F. Marble provenance designation with object based image analysis: State-of-the-art rock fabric characterization from petrographic micrographs. Austrian J. Earth Sci. 2013, 106, 40-49.

24. Magnini, L.; Bettineschi, C. Theory and practice for an object-based approach in archaeological remote sensing. J. Archaeol. Sci. 2019, 107, 10-22. [CrossRef]

25. Luo, L.; Wang, X.; Guo, H.; Lasaponara, R.; Zong, X.; Masini, N.; Wang, G.; Shi, P.; Khatteli, H.; Chen, F.; et al. Airborne and spaceborne remote sensing for archaeological and cultural heritage applications: A review of the century (1907-2017). Remote Sens. Environ. 2019, 232, 111280. [CrossRef]

26. Trier, Ø.D.; Cowley, D.C.; Waldeland, A.U. Using deep neural networks on airborne laser scanning data: Results from a case study of semi-automatic mapping of archaeological topography on Arran, Scotland. Archaeol. Prospect. 2019, 26, 165-175. [CrossRef]

27. Pregesbauer, M.; Trinks, I.; Neubauer, W. An object oriented approach to automatic classification of archaeological features in magnetic prospection data. Surf. Geophys. 2014, 12, 651-656. [CrossRef]

28. Hein, I.; Rojas-Domínguez, A.; Ornelas, M.; D’Ercole, G.; Peloschek, L. Automated classification of archaeological ceramic materials by means of texture measures. J. Archaeol. Sci. Rep. 2018, 21, 921-928. [CrossRef]

29. Ozawa, K. Classification of the keyhole shaped tombs by template matching method. IEEE Trans. Comput. 1978, 27, 462-467. [CrossRef]

30. Parcak, S. Archaeology from Space: How the Future Shapes Our Past; Henry Holt and Co.: New York, NY, USA, 2019.

31. Davis, D.S.; Sanger, M.C.; Lipo, C.P. Automated mound detection using lidar and object-based image analysis in Beaufort County, South Carolina. Southeast Archaeol. 2019, 38, 23-37. [CrossRef]

32. Nyerges, A.E.; Green, G.M. The ethnography of landscape: GIS and remote sensing in the study of forest change in west African Guinea Savanna. Am. Anthropol. 2000, 102, 271-289. [CrossRef] 
33. Canuto, M.A.; Estrada-Belli, F.; Garrison, T.G.; Houston, S.D.; Acuña, M.J.; Kováč, M.; Marken, D.; Nondédéo, P.; Auld-Thomas, L.; Castanet, C.; et al. Ancient lowland Maya complexity as revealed by airborne laser scanning of northern Guatemala. Science 2018, 361, eaau0137. [CrossRef]

34. Menze, B.H.; Ur, J.A. Mapping patterns of long-term settlement in Northern Mesopotamia at a large scale. Proc. Natl. Acad. Sci. USA 2012, 109, E778-E787. [CrossRef]

35. Bintliff, J.; Howard, P.; Snodgrass, A. The hidden landscape of prehistoric Greece. J. Mediterr. Archaeol. 1999, 12, 139-168. [CrossRef]

36. Feiken, H. Dealing with Biases: Three Geo-Archaeological Approaches to the Hidden Landscapes of Italy; Barkhuis: Eelde, The Netherlands, 2014; ISBN 978-94-92444-38-7.

37. Stafford, C.R.; Creasman, S.D. The hidden record: Late Holocene landscapes and settlement archaeology in the Lower Ohio River Valley. Geoarchaeology 2002, 17, 117-140. [CrossRef]

38. Stephens, L.; Fuller, D.; Boivin, N.; Rick, T.; Gauthier, N.; Kay, A.; Marwick, B.; Armstrong, C.G.; Barton, C.M.; Denham, T.; et al. Archaeological assessment reveals Earth's early transformation through land use. Science 2019, 365, 897-902. [CrossRef] [PubMed]

39. S/RES/2347 (2017)|United Nations Security Council. Available online: https://www.un.org/securitycouncil/s/ res/2347-\%282017\%29 (accessed on 6 January 2020).

40. Lasaponara, R.; Masini, N. Space-based identification of archaeological illegal excavations and a new automatic method for looting feature extraction in desert areas. Surv. Geophys. 2018, 39, 1323-1346. [CrossRef]

41. Lauricella, A.; Cannon, J.; Branting, S.; Hammer, E. Semi-automated detection of looting in Afghanistan using multispectral imagery and principal component analysis. Antiquity 2017, 91, 1344-1355. [CrossRef]

42. Tapete, D.; Cigna, F. Detection of archaeological looting from space: Methods, achievements and challenges. Remote Sens. 2019, 11, 2389. [CrossRef]

43. Davis, D.S.; Douglass, K. Aerial and spaceborne remote sensing in African archaeology: A review of current research and potential future avenues. Afr. Archaeol. Rev. 2020, 37. in press. [CrossRef]

44. Lock, G. Using Computers in Archaeology: Towards Virtual Pasts; Routledge: New York, NY, USA, 2003.

45. Richards, J.D.; Ryan, N.S. Data Processing in Archaeology; Cambridge Manuals in Archaeology; Cambridge University Press: Cambridge, UK, 1985.

46. Binford, L.R.; Binford, S.R. A preliminary analysis of functional variability in the mousterian of leuallois facies. Am. Anthropol. 1966, 68, 238-295. [CrossRef]

47. Carneiro, R.L. A quantitative law in anthropology. Am. Antiq. 1970, 35, 492-494. [CrossRef]

48. Tugby, D.J. Archaeological objectives and statistical methods: A frontier in archaeology. Am. Antiq. 1965, 31, 1-16. [CrossRef]

49. Verhoeven, G.; Sevara, C. Trying to break new ground in aerial archaeology. Remote Sens. 2016, 8, 918. [CrossRef]

50. McCoy, M.D.; Ladefoged, T.N. New developments in the use of spatial technology in archaeology. J. Archaeol. Res. 2009, 17, 263-295. [CrossRef]

51. Chase, A.F.; Chase, D.Z.; Fisher, C.T.; Leisz, S.J.; Weishampel, J.F. Geospatial revolution and remote sensing LiDAR in Mesoamerican archaeology. Proc. Natl. Acad. Sci. USA 2012, 109, 12916-12921. [CrossRef]

52. Custer, J.F.; Eveleigh, T.; Klemas, V.; Wells, I. Application of landsat data and synoptic remote sensing to predictive models for prehistoric archaeological sites: An example from the Delaware Coastal Plain. Am. Antiq. 1986, 51, 572-588. [CrossRef]

53. Kirk, S.D.; Thompson, A.E.; Lippitt, C.D. Predictive modeling for site detection using remotely sensed phenological data. Adv. Archaeol. Pract. 2016, 4, 87-101. [CrossRef]

54. Mann, J.; Xutong, N. Statistical Development to Predict Archaeological Site Locations-A Pilot Study; National Resources Conservation Service (NRCS): Troy, AL, USA, 2011.

55. Davis, D.S.; Andriankaja, V.; Carnat, T.L.; Chrisostome, Z.M.; Colombe, C.; Fenomanana, F.; Hubertine, L.; Justome, R.; Lahiniriko, F.; Léonce, H.; et al. Satellite-based remote sensing rapidly reveals extensive record of Holocene coastal settlement on Madagascar. J. Archaeol. Sci. 2020, 115, 105097. [CrossRef]

56. Meredith-Williams, M.G.; Hausmann, N.; Bailey, G.N.; King, G.C.P.; Alsharekh, A.; Al Ghamdi, S.; Inglis, R.H. Mapping, modelling and predicting prehistoric coastal archaeology in the southern Red Sea using new applications of digital-imaging techniques. World Archaeol. 2014, 46, 10-24. [CrossRef] 
57. Verhagen, P.; Whitley, T.G. Integrating archaeological theory and predictive modeling: A live report from the scene. J. Archaeol. Method Theory 2012, 19, 49-100. [CrossRef]

58. Blaschke, T. Object based image analysis for remote sensing. ISPRS J. Photogramm. Remote Sens. 2010, 65, 2-16. [CrossRef]

59. Hay, G.J.; Castilla, G. Geographic Object-Based Image Analysis (GEOBIA): A new name for a new discipline. In Object-Based Image Analysis; Blaschke, T., Lang, S., Hay, G., Eds.; Springer: Heidelberg/Berlin, Germany, 2008; pp. 75-89.

60. Chen, G.; Weng, Q.; Hay, G.J.; He, Y. Geographic object-based image analysis (GEOBIA): Emerging trends and future opportunities. GISci. Remote Sens. 2018, 55, 159-182. [CrossRef]

61. Sevara, C.; Pregesbauer, M.; Doneus, M.; Verhoeven, G.; Trinks, I. Pixel versus object-A comparison of strategies for the semi-automated mapping of archaeological features using airborne laser scanning data. J. Archaeol. Sci. Rep. 2016, 5, 485-498. [CrossRef]

62. Wang, S.; Hu, Q.; Wang, F.; Ai, M.; Zhong, R. A microtopographic feature analysis-based LiDAR data processing approach for the identification of Chu Tombs. Remote Sens. 2017, 9, 880. [CrossRef]

63. Fu, T.; Ma, L.; Li, M.; Johnson, B.A. Using convolutional neural network to identify irregular segmentation objects from very high-resolution remote sensing imagery. J. Appl. Remote Sens. 2018, 12, 1. [CrossRef]

64. Caspari, G.; Crespo, P. Convolutional neural networks for archaeological site detection-Finding "princely" tombs. J. Archaeol. Sci. 2019, 110, 104998. [CrossRef]

65. Casana, J. Regional-scale archaeological remote sensing in the age of big data. Adv. Archaeol. Pract. 2014, 2, 222-233. [CrossRef]

66. Hanson, W.S. The future of aerial archaeology in Europe. Photo Interprétation Eur. J. Appl. Remote Sens. 2010, 46, 3-11.

67. Parcak, S.H. Satellite Remote Sensing for Archaeology; Routledge: New York, NY, USA, 2009.

68. Lamotte, A.; Masson, É. Arché-OBIA: Un concept d'analyse quantitative d'images numériques appliqué aux bifaces du gisement de Gouzeaucourt (Nord, FR). Notae Praehist. 2016, 36, 121-130.

69. Borie, C.; Parcero-Oubiña, C.; Kwon, Y.; Salazar, D.; Flores, C.; Olguín, L.; Andrade, P. Beyond site detection: The role of satellite remote sensing in analysing archaeological problems. A case study in Lithic Resource Procurement in the Atacama Desert, Northern Chile. Remote Sens. 2019, 11, 869. [CrossRef]

70. Opitz, R.; Herrmann, J. Recent trends and long-standing problems in archaeological remote sensing. J. Comput. Appl. Archaeol. 2018, 1, 19-41. [CrossRef]

71. Monna, F.; Magail, J.; Rolland, T.; Navarro, N.; Wilczek, J.; Gantulga, J.-O.; Esin, Y.; Granjon, L.; Allard, A.-C.; Chateau-Smith, C. Machine learning for rapid mapping of archaeological structures made of dry stones-Example of burial monuments from the Khirgisuur culture, Mongolia-. J. Cult. Herit. 2020. [CrossRef]

72. Beaudry, C.; Mouton, J. The Next Generation of Scientists in Africa; African Minds: Cape Town, South Africa, 2018.

73. Thabeng, O.L.; Merlo, S.; Adam, E. High-resolution remote sensing and advanced classification techniques for the prospection of archaeological sites' markers: The case of dung deposits in the Shashi-Limpopo Confluence area (southern Africa). J. Archaeol. Sci. 2019, 102, 48-60. [CrossRef]

74. Klehm, C.; Barnes, A.; Follett, F.; Simon, K.; Kiahtipes, C.; Mothulatshipi, S. Toward archaeological predictive modeling in the Bosutswe region of Botswana: Utilizing multispectral satellite imagery to conceptualize ancient landscapes. J. Anthropol. Archaeol. 2019, 54, 68-83. [CrossRef]

75. Pedró, F.; Subosa, M.; Rivas, A.; Valverde, P. Artificial Intelligence in Education: Challenges and Opportunities for Sustainable Development; UNESCO: Paris, France, 2019.

76. Kansa, E.C.; Kansa, S.W.; Wells, J.J.; Yerka, S.J.; Myers, K.N.; DeMuth, R.C.; Bissett, T.G.; Anderson, D.G. The digital index of north american archaeology: Networking government data to navigate an uncertain future for the past. Antiquity 2018, 92, 490-506. [CrossRef]

77. Kansa, E.C.; Kansa, S.W. Toward a do-it-yourself cyberinfrastructure: Open data, incentives, and reducing costs and complexities of data sharing. In Archaeology 2.0: New Approaches to Communication and Collaboration Location; Kansa, E.C., Kansa, S.W., Watrall, E., Eds.; Cotsen Digital Archaeology Series; Cotsen Institute of Archaeology: Los Angeles, CA, USA, 2011.

78. Marwick, B. Computational reproducibility in archaeological research: Basic principles and a case study of their implementation. J. Archaeol. Method Theory 2017, 24, 424-450. [CrossRef] 
79. Quintus, S.; Day, S.S.; Smith, N.J. The efficacy and analytical importance of manual feature extraction using lidar datasets. Adv. Archaeol. Pract. 2017, 5, 351-364. [CrossRef]

80. Hegyi, A.; Vernica, M.-M.; Drăguț, L. An object-based approach to support the automatic delineation of magnetic anomalies. Archaeol. Prospect. 2019. [CrossRef]

81. Katz, J.S. Geographical proximity and scientific collaboration. Scientometrics 1994, 31, 31-43. [CrossRef]

82. Glänzel, W.; Schubert, A. Analysing scientific networks through co-authorship. In Handbook of Quantitative Science and Technology Research; Springer: Berlin, Germany, 2004; pp. 257-276.

83. Cerra, D.; Plank, S.; Lysandrou, V.; Tian, J. Cultural heritage sites in danger-Towards automatic damage detection from space. Remote Sens. 2016, 8, 781. [CrossRef]

84. Luo, L.; Wang, X.; Guo, H.; Liu, C.; Liu, J.; Li, L.; Du, X.; Qian, G. Automated extraction of the archaeological tops of qanat shafts from vhr imagery in Google Earth. Remote Sens. 2014, 6, 11956-11976. [CrossRef]

85. Soroush, M.; Mehrtash, A.; Khazraee, E.; Ur, J.A. Deep learning in archaeological remote sensing: Automated qanat detection in the kurdistan region of Iraq. Remote Sens. 2020, 12, 500. [CrossRef]

86. Holon, I.Q. Artificial Intelligence \& Global Education; Holon IQ: San Francisco, CA, USA, 2019.

87. Gaines, S.W.; Most, R. Computerized data sharing: The SARG example of cooperative research. In Computer Applications in Archaeology; Laflin, S., Ed.; Center for Computing and Computer Science, University of Birmingham: Birmingham, UK, 1982; pp. 19-32.

88. Chenhall, R.G. The archaeological data bank: A progress report. Comput. Humanit. 1971, 5, $159-169$. [CrossRef]

89. Colwell, C. Collaborative archaeologies and descendant communities. Annu. Rev. Anthropol. 2016, 45, 113-127. [CrossRef]

90. Douglass, K.; Morales, E.Q.; Manahira, G.; Fenomanana, F.; Samba, R.; Lahiniriko, F.; Chrisostome, Z.M.; Vavisoa, V.; Soafiavy, P.; Justome, R.; et al. Toward a just and inclusive environmental archaeology of southwest Madagascar. J. Soc. Archaeol. 2019. [CrossRef]

(C) 2020 by the author. Licensee MDPI, Basel, Switzerland. This article is an open access article distributed under the terms and conditions of the Creative Commons Attribution (CC BY) license (http://creativecommons.org/licenses/by/4.0/). 